\title{
Effectiveness of The Implementation of Compulsory Primary Education Policy in Bolaang Mongondow District North Sulawesi Province
}

\author{
$1^{\text {st }}$ Abdul Rahman Dilapanga \\ Public Administration \\ Universitas Negeri Manado \\ Manado, Indonesia \\ abdulrahmandilapanga@unima.ac.id
}

\author{
$2^{\text {nd }}$ Jeane Mantiri \\ Public Administration \\ Universitas Negeri Manado \\ Manado, Indonesia \\ Lithajeane19@gmail.com
}

\author{
$5^{\text {th }}$ Apeles Lexi Lonto \\ Pancasila and Civic Education \\ Department \\ Universitas Negeri Manado \\ Tondano, Indonesia \\ lexi.lonto@unima.ac.id
}

\author{
$3^{\text {rd }}$ Revolson A. Mege \\ Faculty of Mathematic and Science \\ Universitas Negeri Manado \\ Manado, Indonesia \\ ramege@unima.ac.id
}

\author{
$4^{\text {th }}$ Evie Elfira Masengi \\ Public Administration \\ Manado, Indonesia \\ Eviemasengi@unima.ac.id
}

\begin{abstract}
Every citizen is required to attend the primary education and the government has the obligation to fund it. Based on the data from the Central Statistics Agency of Bolaang Mongondow Regency in 2014. The average length of schooling (RLS) of Bolaang Mongondow Regency is 7.48 years, or have not graduated from Junior High School/ Madrasah Tsanawiyah. This phenomenon illustrates the existence of problems related to the effectiveness of the implementation of compulsory primary education policy. This study used qualitative research method, with the technique of collecting data through interviews, observation and documentation. The informants in this study were determined purposively (purposive sampling), using snowball sampling technique. The Data analysis that is being used is an interactive analysis model from Miles and Huberman i.e.: Reduction, Data Display and Conclusion / Verification. By making the APM(Real Enrollment Rates) / APK(Temporary Calculation Number) a value of effectiveness, the effectiveness of the implementation of compulsory primary education policy in Bolaang Mongondow District is summarized as follows: 1. The policy of compulsory primary education at Elementary School/ Madrasah Ibtidaiyah (MI) level in Bolaang Mongondow District had fulfilled and even exceeded the value of effectiveness that was set long before so that it could be categorized as very effective. 2 . The policy of compulsory education at the Junior High School level in Bolaang Mongondow District even though the APK had reached $80.05 \%$ and is classified as good, but had not reached the point of effectiveness value $(95 \%)$ which is set nationally so that it is categorized as incomplete (not effective). 3. By looking at the composition of credible schools in both elementary and junior high schools, those who do not have SLB (School with Special Needs) give a message that children with special needs have not been touched by the compulsory primary education policy in Bolaang Mongondow District.
\end{abstract}

Keywords - Effectiveness, Policy Implementation, Compulsory Education, Primary Education

\section{INTRODUCTION}

Compulsory primary education, had actually been proclaimed and implemented since May 2, 1984, which was preceded by a six-year compulsory education movement or compulsory elementary school education. Ten years later, on May 2, 1994, it was increased to become a Compulsory Education for Nine Years Primary Education, namely compulsory six-years education in elementary/ equivalent and three years in junior high school/ equivalent. Nationally according to the Presidential Instruction No. 5 of 2006 concerning the National Movement to Accelerate Completion of Compulsory Primary Education, instructs to: (a) increase the percentage of primary / madrasah / equivalent primary school students aged $7-12$ years or real enrollment rates (APM) at least to $95 \%$ at the end of 2008; (b) increase the percentage of junior high school / madrasah tsanawiyah / equivalent education students aged 13-15 years or temporary calculation number (APK) at least to $95 \%$ at the end of 2008. Based on data from the Bolaang Mongondow Regency Central Bureau of Statistics in 2014 [1] the average length of schooling (RLS) of Bolaang Mongondow Regency residents was 7.48 years, in other words, the average citizens were only graduated from elementary school and did not complete their junior high school level. The phenomenon and data described above illustrates the existence of problems related to the effectiveness of the implementation of compulsory primary education in the Bolaang Mongondow Regency. In connection with the effectiveness of policy implementation, [2] asks the question "has the desired results been achieved? Based on the background of the research described above, the researcher determined the main focus of this study was the effectiveness of the mandatory policy implementation of primary education in Bolaang Mongondow District, North Sulawesi Province. Therefore, the formulation of the 
problem in this study was formulated in the following research questions: "What is the effectiveness of the implementation of the policy of compulsory primary education in Bolaang Mongondow Regency, North Sulawesi Province?"

\section{RESEARCH METHODS}

This study used qualitative research methods, with the main focus of the research is the effectiveness of the implementation of primary education compulsory education policy which is focused on the achievement of compulsory primary education programs with data collection techniques through interviews, observation and documentation. The informants in this study were determined purposively (purposive sampling), with snowball sampling technique. Data analysis that is being used is an an interactive analysis model from [3], i.e.: Data Reduction, Data Presentation and Verification.

\section{RESULTS AND DISCUSSION}

\section{A. Results}

In general, activities relate to the extent to which the organization carries out all its main tasks or achieves all the goals or objectives that have been set. The aim or objective of the nine-year compulsory education policy is for all school-age children (7-12) years old, and children aged (1315) to have primary education. Primary education is the level of education that underlies secondary education in the form of elementary schools (SD) and Madrasah Ibtidaiyah (MI) or other equivalent forms as well as junior high schools (SMP) and Madrasah Tsanawiyah (MTs), or other equivalent forms.

The indicator of achievement or effectiveness of compulsory education is explained or illustrated based on the Real Enrollment Rates (APM) and Temporary Calculation Number (APK). Data on the implementation of compulsory primary education policy in Bolaang Mongondow District, North Sulawesi Province are:

a. The Real Enrollment Rates Elementary School in 2014 was $95.7 \%$, the average APM for elementary school in the last five years (2010 to 2014) was $94.14 \%$, while the Real Enrollment Rates for junior high school / MTs in 2014 was $62.46 \%$ with on average in the last five years was $62.98 \%$.

b. The Temporary Calculation Number of Elementary School / MI in 2014 was $111.3 \%$, on average in the last five years (2010 to 2014) of $103.47 \%$, while the temporary calculation number of Junior High School/ SMPLB / MTs in 2014 was $80.05 \%$ with an average in the last five years is $79.81 \%$.

c. Nationally according to the Presidential Instruction No. 5 of 2006 concerning the National Movement to Accelerate Completion of Compulsory Primary Education, instructs to: (a) increase the percentage of students in madrasah elementary school / equivalent education students aged $7-12$ years or real enrollment rate (APM) at least to $95 \%$ at the end of 2008; (b) increase the percentage of junior high school / madrasah tsanawiyah / equivalent students aged 13-15 years or temporary calculation number (APK) at least to $95 \%$ at the end of 2008. Comparing the achievement criteria of compulsory education with APK 95\% according with the Presidential Instruction, the learning of basic education at the junior high school level in Bolaang Mongondow District has not been effective.

d. Another indicator that measure of the achievement of compulsory primary education is the graduation and learning outcomes of students. Based on the results of the documentation analysis, the elementary school / MI graduation rates in the last four school years $(2010 / 2011$ to $2013 / 2014$ ) averaged $100 \%$, with the learning outcomes of students in the last four school years averaging 7.28, while the achievement of student learning outcomes in 2013/2014 was an average of 7.5. These results indicate that from year to year there is an increase in the achievement of learning outcomes of students at the elementary school / MI level. While the achievement of graduation rates at the junior high school level in the last four school years averaged $99.78 \%$, with learning outcomes stagnating at an average of 7.5. These results indicated that during the last four school years the achievement of learning outcomes of junior high school / MTs students obtained through UAN did not experience an increase or decrease.

e. Other goals of compulsory education are equity and increasing access to primary education for primary education needs. The spread of schools to rural areas has opened up access for the community to meet primary education needs in Bolaang Mongondow District, especially at the elementary school level. While at the junior high school level, there are still efforts to add new school units to bring access to primary education for the community.

f. By looking at the composition of schools both at elementary and junior high school level, those who do not have SLB give a message that children with special needs have not been touched by the compulsory primary education policy in Bolaang Mongondow District.

\section{B. Discussion}

The effectiveness criteria carried out in the implementation of the compulsory primary education policy in Bolaang Mengondow Regency need to be a concern, considering this effectiveness criterion is used to answer the question of the effectiveness of the compulsory basic education policy in Bolaang Mongondow District? This criterion is used to assess the extent to which the level of output of the policy and the implementation process reaches the stated goals.[2] stated that: effectiveness with regard to whether an alternative achieves the results (effect) expected, or achieves the objectives of the action. With understanding, the effectiveness criteria are one of the measurements to produce information about program performance related to the compulsory primary education policy assessment in Bolaang Mongondow District. The next question is whether temporary calculation number compulsory primary education in Bolaang Mongondow District has achieved the established effectiveness value? Based on the results of the research that was stated earlier that in 2014 the elementary 
school / MI temporary calculation number was $111.3 \%$, while the junior high school / MTs temporary calculation number was $80.05 \%$. If the temporary calculation is used as a value of effectiveness, then it can be said that the compulsory primary education policy at the elementary school/ MI level in Bolaang Mongondow District has exceeded even the value of effectiveness that was set long before so that it can be categorized as very effective. On the other hand, at the level of junior high school / MTs, although the temporary calculation number has reached $80.05 \%$ and is classified as good, it has not yet reached the national effectiveness $(95 \%)$ so that it is categorized as not yet effective. Basically, the effectiveness according to Mahmudi in [4] is a "comparison between outcome and output". This view can be the overcome that the greater the output contribution to the achievement of goals, the more effective the policy is implemented. In this study, effectiveness is understood as an effort to obtain information about whether the mandatory primary education policy objectives in Bolaang Mongondow Regency are achieved according to their objectives.

\section{CONCLUSION}

By making the real enrollment rates / temporary calculation number a value of effectiveness, the effectiveness of the implementation of compulsory primary education policy in Bolaang Mongondow District is summarized as follows:

1. The policy of compulsory education of primary education at the elementary school/ MI level in Bolaang Mongondow District has fulfilled and even exceeded the value of effectiveness that was set long before so that it can be categorized as complete (very effective).

2. Compulsory education at junior high school level in Bolaang Mongondow District even though the temporary calculation number has reached $80.05 \%$ and is classified as good, but has not reached the point of effectiveness value (95\%) which is set nationally so that it is categorized as not yet complete.

3. By looking at the composition of schools both at elementary and junior high school level, those who do not have SLB give a message that children with special needs have not been touched by the compulsory education of primary education in Bolaang Mongondow District.

\section{ACKNOWLEDGMENT}

I would like to address my special acknowledgment to Prof. Dr.Drs. Budiman Rusli, MS, Dr. Heru Nurasa, MA, Dr. Sony Nulhaqim, S.Sos, M.Si from the Postgraduate Program of FISIP, Padjadjaran University, Bandung. The same utterance were addressed to Dr. Lexi Lonto, M.Si (Dean of FIS Unima) who gave the opportunity to the writer to take part in this activity.

\section{REFERENCES}

Mongondow: Badan Pusat Statistik, 2014.

[2] W. N. Dunn, Pengantar analisis kebijakan publik. Gadjah Mada University Press, 2000.

[3] A. Miles, Matthew, B \& Huberman, Micahel, Qualitative Data Analysis. Jakarta: University of Indonesia Press, 1992.

[4] A. R. Dilapanga, Evaluasi Kebijakan Wajib Belajar Pendidikan Dasar. Manado: Yayasan Makaria Waya, 2016. 